\title{
Antibiyotik Yönetimi Ekibi ve Eczacının Rolü
}

\section{Antibiotic Stewardship Team and the Role of Pharmacist}

\author{
Sümeyye Zeynep ÇAVDAR ${ }^{1}$, Kutay DEMIRKAN² ${ }^{2}$ Aygin BAYRAKTAR EKINCIOG̃LU², Serhat ÜNAL ${ }^{3}$
}

\author{
${ }^{1}$ Hacettepe Üniversitesi Eczacilık Fakültesi, Ankara, Türkiye \\ ${ }^{2}$ Hacettepe Üniversitesi Eczacılık Fakültesi, Klinik Eczacılık Anabilim Dalı, Ankara, Türkiye \\ ${ }^{3}$ Hacettepe Üniversitesi Tıp Fakültesi, İnfeksiyon Hastalıkları ve Klinik Mikrobiyoloji Anabilim Dalı, Ankara, Türkiye
}

\section{ÖZET}

\begin{abstract}
Antibiyotiklerin uygunsuz kullanımı direnç gelişme riskini artırmaktadır. Direnç gelişimi hastanede kalış süresinin uzamasına, mortalite ve tıbbi bakım maliyetlerinin artmasına neden olmaktadır. Antibiyotik yönetimi, dirençli bakterilerin ortaya çıkmasını ve yayılmasını sınırlayarak klinik sonuçları optimize etmeyi amaçlamaktadır. Antibiyotik yönetim programı, iki çekirdek strateji ve çeşitli tamamlayıcı stratejilerden oluşmaktadır. Kapsamlı antibiyotik yönetim programları, antibiyotik kullanımında ve maliyetlerde azalma olduğunu göstermiştir. İeal antibiyotik yönetim programı; infeksiyon hastalıkları uzmanı doktor, infeksiyon hastalıkları konusunda eğitim almış klinik eczacı, klinik mikrobiyolog, bilgi sistemi uzmanı, infeksiyon kontrol profesyoneli ve hastane epidemiyoloğunu içeren multidisipliner bir ekipten oluşmaktadır. Klinik eczacı, antibiyotiklerin uygun kullanımı konusunda bilgili olmalı, bu uzmanlığı edinmesi ve sürdürmesi için uygun eğitim programları eczacılara sunulmalıdır. Antibiyotiklerin akılcı kullanımını teşvik etmek, infeksiyonların yayılmasını azaltmak, sağlık çalışanlarını, hastaları ve halkı eğitmek gibi antibiyotik yönetimi ekibinde klinik eczacıların önemli rolü ve sorumlulukları bulunmaktadır. Bu konuda donanımlı eczacıların antibiyotik yönetimi ekibine aktif katıımları sağlanmalıdır.
\end{abstract}

Anahtar Kelimeler: Antibiyotik direnci; Antibiyotik yönetimi; Eczacının rolü

\section{SUMMARY}

\section{Antibiotic Stewardship Team and the Role of Pharmacist}

Sümeyye Zeynep ÇAVDAR', Kutay DEMIRKAN² ${ }^{2}$, Aygin BAYRAKTAR EKINCIOG̃LU², Serhat ÜNAL ${ }^{3}$

\footnotetext{
${ }^{1}$ Faculty of Pharmacy, University of Hacettepe, Ankara, Turkey

${ }^{2}$ Department of Clinical Pharmacy, Faculty of Pharmacy, University of Hacettepe, Ankara, Turkey

${ }^{3}$ Department of Infectious Diseases and Clinical Microbiology, Faculty of Medicine, University of Hacettepe, Ankara, Turkey
}

\begin{abstract}
Inappropriate use of antibiotics increases the risk of resistance development. Development of resistance causes prolongation of hospital stay, increased mortality and health care costs. Antibiotic stewardship seeks to optimize clinical results by limiting the emergence and transmission of resistant bacteria. Antibiotic stewardship program consists of two core strategies and various complementary strategies. Comprehensive antibiotic stewardship programs have demonstrated decreased in antibiotic use and costs. Ideally, antibiotic stewardship program consists of a multidisciplinary team including infectious disease specialist doctor, clinical pharmacist trained in infectious diseases, clinical microbiologist, information systems specialist, infection control professional and hospital epidemiologist. The clinical
\end{abstract}


pharmacist should be knowledgeable about the appropriate use of antibiotics, and appropriate training programs should be made available to achieve and maintain this expertise. There are important roles and responsibilities of the clinical pharmacists in the antibiotic stewardship team as to promote the optimal use of antibiotics, reduce transmission of infections, educate health professionals, patients, and the public. Hence, an active participation of qualified pharmacists should be ensured in the antibiotic stewardship team.

Key Words: Antibiotic resistance; Antibiotic stewardship; Role of pharmacist

A tibiyotikler, hastanelerde en sik reçete edilen ilac grupları arasında yer alırken, hastaların yaklașık \%30-50'sinde yatıs süresince en az bir kez antibiyotik tedavisi uygulandığı bilinmektedir ${ }^{[1]}$. Amerika Birleșik Devletleri (ABD)'nde antibiyotik reçetelerinin \%50'sinden fazlasında; ilac seçimi, uygulama yolu, doz ya da tedavi süresinin uygunsuz olabileceği tahmin edilmektedir ${ }^{[2]}$. Yapilan çalıșmalarda, acil servis ve yoğun bakım üniteleri gibi bölümlerde uygunsuz antibiyotik tedavisinin yüksek oranda olduğu gösterilmiștir ${ }^{[3]}$. Antibiyotiklerin uygunsuz kullanımı; bakteriyel direnç artıșı, infeksiyonlarla ilgili artan mortalite, klinik bașar1sızlık ve hastanede kalıs süresinin uzaması gibi önemli sorunların ortaya çkmasına yol açabilmektedir $^{[2-5]}$. Antibiyotik tüketiminin yaklașı \%80'i ise toplumda gerçekleșmekte; bunun en az yarısı da coğunlukla viral infeksiyon gibi yanlıș endikasyona dayanmaktadır. Antibiyotiklerin cok kısa bir süre, cok düsük bir doz veya yanlıs tanı nedeniyle hatalı kullanımı her zaman bakteriyel direnç olasılığını artırmaktadır [6].

Direnç söz konusu olduğunda tedavi için gerekli antibiyotiğin daha pahalı olması, hastanede kalıs süresinin uzaması, tanı testleri ve yoğun bakım ihtiyacının artması, izolasyon önleminin alınması ve komplikasyon insidansının daha yüksek olması gibi ortaya çkan giderler nedeniyle hasta bakım maliyetinde artıș görülmektedir ${ }^{[6]}$. Duyarlı ve dirençli bir bakteri tedavisi karșılaștırıldığında yaklașık 7000-29.000 dolar arasında değișen bir maliyet söz konusu olabilmektedir. "Infectious Diseases Society of America (IDSA)", ABD'de 2004 yılı için antibiyotik dirençli infeksiyonların toplam maliyetinin 5 milyar dolardan fazla olduğunu tahmin etmektedir ${ }^{[5]}$. "Centers for Disease Control and Prevention (CDC)", ABD'de her yll, en az 2 milyon kișinin antibiyotiklere dirençli bir veya daha fazla bakteri ile ciddi infeksiyonlara yakalandığını tahmin etmektedir. Her yıl en az 23.000 kiși antibiyotiklere dirençli infeksiyonların doğrudan bir sonucu olarak ölmektedir ${ }^{[7]}$.
Bakteri direnci ile mücadele edebilmek için yeni antibiyotikler geliștirilmiștir ancak onların da klinik kullanımının artmasıyla birlikte bakteri sușlarının duyarlılığı azalmıș veya bu yeni ajanlara karșı direnç gelișmiștir ${ }^{[8]}$.

Antibiyotik direncinin ortaya cıkmasıyla IDSA, Amerika Sağlık Epidemiyolojisi Derneği ve Amerikan Sağlık Sistemi Eczacıları Derneği de dahil olmak üzere ceșitli kurulușlar günümüz sağlık sisteminde önemli bir role sahip olan antibiyotik yönetimini belirlemiștir ${ }^{[9]}$. Bașarılı bir antibiyotik yönetim programı; doktorun karar verme ve reçeteleme sisteminin altyapısını desteklemek için cok yönlü ve cok disiplinli bir yaklașım kullanır. Antibiyotik yönetiminin ana hedefi hasta sonuclarını iyileștirmek amacıyla uygun antibiyotiğin seçimi, doz, uygulama yolu ve tedavi süresi dahil olmak üzere antibiyotiklerin terapötik kullanımını optimize etmektir. İkinci hedefi, antibiyotik direncinin ortaya cıkmasını azaltmak, patojenik organizmaların seleksiyonunu azaltmak ve hasta güvenliğini artırmak; üçüncü hedefi de sağlık harcamalarında azalma sağlamaktır. Antibiyotik yönetim programlarının, infeksiyonu önlemede klinik olarak bașarılı ve maliyet-etkin olduğuna dair veriler giderek artmaktadir ${ }^{[7,10]}$.

\section{ANTIBiYYOTIK YÖNETIMI}

Antibiyotik yönetimi, sağlık çalıșanları tarafından antibiyotiklerin bilinçli kullanımıdır; infeksiyon süphesi durumunda, hasta için en uygun antibiyotiğin, tedavi süresinin, ilaç dozunun ve uygulama yolunun seçimi anlamina gelir ${ }^{[5,11]}$. Antibiyotik yönetimi, reçetelemeyi optimize edebilmek için politikalar, kılavuzlar, sürveyans/yaygınlık raporlar1, eğitim ve uygulama denetimi de dahil olmak üzere cok yönlü bir yaklașımdır ${ }^{[1]}$. Antibiyotik yönetiminin hedefi; toksisite ve diğer advers olayları en aza indirgeyerek, antibiyotik dirençli sușların ortaya çımasını sınırlayarak antibiyotik kullanımı ile ilgili en iyi klinik sonuçlara ulașmaktır ${ }^{[12]}$. 
Antibiyotik yönetiminin üc temel amacı vardır. İlki, her hastanın doğru doz ve süre ile en uygun antibiyotiği almasına yardımcı olmak için sağlık hizmeti uygulayıcıları ile calısmaktır. İnfekte olan bir hastanın optimal bakımı; doğru, uygun dozda ve en az zarar olasılığı olan antibiyotik ile tedavi edilmesi anlamına gelir. Antibiyotik kullanımını optimize etmeyi amaçlayan programların bir diğer yararı maliyeti azaltmak için daha az dozda antibiyotik kullanılması ve daha az pahalı olan antibiyotiğin seçilmesidir ${ }^{[13]}$. Kapsamlı programlar ile yıllık 200.000-900.000 dolar tasarruf sağlandığı gösterilmiștir ${ }^{[7,13-15]}$.

İkinci amaç, antibiyotiklerin așırı, yanlıs ve kötüye kullanımını önlemektir. Hastanede ve ayaktan tedavi hizmeti sunulan kurulușlarda gerekli olmayan durumlarda antibiyotik kullanılabilmektedir. Kültuir sonuçlarına göre antibiyotik ve doz ayarlanmasının yetersizliği veya toplumda kazanılmıs infeksiyonlar için dirençli organizmaları kapsayacak sekilde genis spektrumlu kombine antibiyotik tedavisinin kullanılması yaygın bir sekilde görülmektedir.

Úçüncü amaç ise direnç gelișimini en aza indirmektir. Yaygın ve yanlıs antibiyotik kullanımının, antibiyotik direnci gelișimiyle ilișkili olduğu gösterilmiștir. Ayrıca, antibiyotik direnci artan mortalite ve morbidite ile de iliskilidir. Hem bireysel hem de toplumsal düzeyde antibiyotik kullanımına bağlı olarak duyarlılık değișebilmektedir. Antibiyotiklere maruz kalan hastaların dirençli organizmalar tarafından infekte olma riski daha fazladır. Clostridium difficile kaynaklı ishal gelișiminin en sik nedeni, dirençli gram-negatiflere karș tercih edilen karbapenem ve sefalosporin grubu antibiyotiklere maruz kalmaktır ${ }^{[13]}$

\section{ANTIBiYYTIK YÖNETIMi EKIBi}

İdeal antibiyotik yönetimi ekibi; bir infeksiyon hastalıkları uzmanı doktor, infeksiyon hastalıkları konusunda eğitim almış bir klinik eczacı, bir klinik mikrobiyolog, bir bilgi sistemi uzmanı, bir infeksiyon kontrol profesyoneli ve bir hastane epidemiyoloğu içeren multidisipliner gruptan olușmaktadir ${ }^{[5,14,16]}$. Antibiyotik yönetim programı genellikle infeksiyon hastalıkları uzmanı doktor tarafından ya da bir infeksiyon hastalıkları uzmanı doktor ve infeksiyon hastalıkları konusunda eğitim almış bir klinik eczacı tarafından ortaklașa yönetilir ${ }^{[14]}$.
İnfeksiyon kontrol profesyoneli, antibiyotik yönetimi ekibi tarafından uygulanan stratejilerin sonuçlarının değerlendirilmesine yardımcı olabilecek, hastane infeksiyonları ile ilgili detaylı veri toplamakla görevlidir ${ }^{[17]}$. Ekip içerisinde yer alan hastane epidemiyologları, sürveyans konusunda uzmanlığa sahiptir ${ }^{[17]}$. Sürveyans sonuclarına göre tavsiyelerin uygulanması için gerekli bilgisayar desteğini ise bilgi sistemi uzmanı sağlamaktadır ${ }^{[14]}$

Bașarılı bir antibiyotik yönetim programı, programın ișlevi, uygulanması ve tasarımı için en az bir tane infeksiyon hastalıkları uzmanı doktor gereklidir. Tedavi prensipleri, antibiyotik kısitlama politikaları ya da en iyi kanit ve uygulamaya dayalı diğer önlemler için infeksiyon hastalıkları uzmanı doktor tarafindan denetim gereklidir. Orta veya büyük ölçekli hastanelerde yönetim programı verilmesine yönelik harcanan zamanın bir kımı klinik danıșma, araștırma ve öğretim için de ayrılmalıdır. Eğitim kurumu dıșındaki daha küçük hastanelerde, multidisipliner antibiyotik yönetimi ekibini olușturabilecek personel bulunmadığından böyle bir program desteklenemeyebilir. Yapilan calıșmalarda, infeksiyon hastalıkları uzmanı bir doktor ve bir klinik eczacı liderliğindeki antibiyotik yönetimi ekibinin haftada 3 gün çalıșması sonucu 120 yataklı bir hastanede 1 yl içinde antibiyotik maliyetinde 170.000 dolar azalma gösterilmiștir. Antibiyotik yönetim programı kapsamında infeksiyon hastalıkları uzmanı doktorun her hafta toplamda 8-12 saat calıșması ve klinik eczacının kısmi zamanlı katkısı sayesinde hastanede önemli maliyet tasarrufu söz konusu olabilmektedir. Böylece kücük hastanelere de antibiyotik yönetim faaliyetleri için destek verilebilir ${ }^{[17]}$

Büyük hastanelerde, antibiyotik yönetimi faaliyetlerini gerçekleștiren infeksiyon hastalıkları uzmanı doktora yapilan geri ödeme yetersiz olabilmektedir. Hastanede calısan infeksiyon hastalıkları uzmanı doktorların sadece \%18'ine, antibiyotik yönetim faaliyetleri nedeniyle hastane tarafından geri ödeme yapıldığı bildirilmiștir. Bir doktorun ayırdığı zaman için ödenen herhangi bir ek maas, antibiyotik yönetim programlarında tasarruf edilen maliyet bedelini așabileceğinden, bu durum hastanelerin fırsat kaybettiği anlamına gelebilmekte$\operatorname{dir}^{[17]}$. 
Klinik mikrobiyoloji laboratuvarı, antibiyotik yönetim programının ișlevi için önemli bir bileșendir. Antibiyotik yönetimi ekibi tarafından hastanelerde antibiyotik direncinin mevcut yükünün belirlenmesinde, antibiyotik kullanımının kısıtlanmasında veya değerlendirme yapilabilmesinde "antibiyotik direnç oranları" büyük önem taşımaktadır. Özellikle yoğun bakım üniteleri gibi bazı alanlara özgü antibiyogramların hazırlanması, yerel sorunların tanımlanmasına olanak sağlayabilmektedir. Ayrıca, bir veya üc aylik dönemlerde mevcut direnç verilerine sahip eğilimleri yakından takip etmeye imkan tanımakta ve iyi tasarlanmıs calıșmaları kolaylastırmaktadır. Klinisyenler için antibiyogramların yayginlastırılmasıyla yerel duyarll1lk durumları göz önünde tutularak daha uygun ampirik tedavi secilebilmektedir. Ancak izolatların mutlak sayısı cok az olduğunda antibiyogram sonuçlarının yorumlanması konusunda klinisyenlerin daha dikkatli olmalar1 gerekmektedir ${ }^{[17]}$.

Antibiyogramların uygun sekilde calıșlması ve raporlanması için "Clinical and Laboratory Standards Institute (CLSI)" tarafından bir rehber yayınlanmıștır ${ }^{[14,17]}$. Mikrobiyoloji duyarlllik test sonuçlarının zamanında ve doğru raporlanması ile daha uygun ve tedavi odakl bir secim yapilabilmekte ve genis spektrumlu antibiyotik kullanımını azaltmaya yardımcı olunabilmektedir. Böylece mikroorganizmaya özgü tedavi seçimi sağlanabilmektedir. Yeni biyoteknoloji kökenli testlerin artması, laboratuvar hizmetlerinin merkezileșmesi ve vasıflı ișçi yetersizliği gibi durumlar, klinik mikrobiyologların günümüzde karșılaștıkları önemli sorunlar arasında yer almaktadır. Bu sorunların giderilebilmesi için antibiyotik yönetim programının eğitsel girișimleri ile uygun kültür bakılmasına, testlerin sunulmas1na, laboratuvar kaynaklarının akılcı kullanılmasına ve maliyet açısından tasarrufun sağlanabilmesine yönelik tavsiyelerde bulunulmalıdır ${ }^{[17]}$.

Hastanelerde dirençli mikroorganizmaların yayılması, infeksiyon kontrolü alanında calısanlar için büyük bir sorundur. İnfeksiyon kontrolü ve antibiyotik yönetim programları arasında ișbirliği olması kaçınılmazdır. Antibiyotik yönetim programları, hedeflenen birimlerde antibiyotiklerin k1sıtlanması ve izlemi ile bulașları kontrol etmeye yardımc1 olabilmektedir. Bu nedenle hastanede antibiyotik yönetim programı ile infeksiyon kontrol programının birlikte uyumlu bir sekilde calıșması gerekmektedir. Böyle bir issbirliği, direnci azaltmak ve hasta sonuçlarını iyileștirmek için sinerji olusması açısından önemli bir firsattır.

Antibiyotik yönetim programının gelistirilmesi ve devamllığının sağlanması için program finansmanı, kurumsal politika ve doktor özerkliği gibi konuların hastane yönetimi tarafından dikkate alınarak, gerekli desteğin verilmesi gerekmekte$\operatorname{dir}^{[14,17-19]}$.

\section{Antibiyotik Yönetimi Ekibine Neden İhtiyaç Var?}

Antibiyotiklerin uygun kullanımı, etkinliklerinin korunması için önemlidir. Uzun yıllar boyunca hastanelerde infeksiyon veya hijyen kontrol eksikliği nedeniyle antibiyotik direnci gelișimi gözlenmiștir. Ancak antibiyotik direncindeki artıș, günümüzde toplumsal alanda da hissedilmekte ve özellikle toplumun infeksiyonlara karșı en savunmasız kısmını, yani cocuk ve yasslları etkilemektedir. Bu nedenle toplumda, antibiyotik yönetimine tıbbi ve toplumsal bir ihtiyac duyulmaktadır. Çoğu ülkede hastanelerde antibiyotik yönetim programları yeni yeni uygulanmaktadır. Ancak toplumda, uzun süreli bakım hizmeti sunan kurulușlarda ve birinci basamak sağlık kuruluşlarında bu programlar neredeyse hic uygulanmamaktadır. Antibiyotik yönetimi, toplumda kazanılmıs infeksiyonların tedavisinde kullanılan antibiyotiklerin klinik basarısını en üst düzeye çlkarmayı ve direnç gelișimi gibi istenmeyen sonuçları en aza indirgemeyi amaçlamaktadır ${ }^{[20]}$.

Antibiyotik direnci, antibiyotik yönetim programlarının yaygınlașması için tetikleyici bir faktör olmasına rağmen bu programların diğer hasta güvenliği ile ilgili sorunlar için de önemli olduğu unutulmamalıdır. $C$. difficile, hastanede hastalar için önemli bir tehdittir. C. difficile'nin BI/ NAP1 epidemik susunun ortaya çkması mortalite ve morbiditede belirgin artıslara yol açmıstır. CDC, ABD'de her yll hastanede yatan hastalarda 14.000 ölümle sonuçlanan yaklașik 250.000 C. difficile olgusu olduğunu tahmin etmektedir. Antibiyotik yönetiminin hastanelerde $C$. difficile ile mücadelede son derece etkili bir strateji olduğu kanıtlanmıștır. ABD'de birçok tek merkezli çalısma, yönetim programlarının uygulanmasını takiben $C$. difficile kaynaklı infeksiyonlarda önemli azalmalar olduğunu göstermiștir ${ }^{[7]}$. 
Antibiyotik yönetim programlarının uygulanmasıyla, infeksiyonların iyileșmesinde $\% 70$ artıs ve tedavi bașarısızlığında \%80 azalma gözlenirken; cerrahi profilakside antibiyotik kullanımının iyileștirilmesinde ve böbrek yetmezliği olan hastalarda optimal dozlama için klinisyenlere yardımcı etkisi de gösterilmiștir. Bu calıșmalar incelendiğinde uygun cerrahi profilaksi bașlanan hastalarda, yönetim programları hem cerrahi yara infeksiyonlarını önlemeye katkıda bulunmakta hem de advers olayları azaltmaktadır ${ }^{[7]}$.

\section{ANTIBiYYOTIK YÖNETIM PROGRAMININ UYGULANMASI}

Antibiyotik yönetim programları, hastaneye yatış riskinin en aza indirilmesi, sağllk harcamalarının ve antibiyotik direncinin azaltılması için önleyici stratejileri geliștirirken; hastaneler, birinci basamak sağllk kurulușu ve yetkili kamu kurum ve kuruluşları tarafından da devamlı olarak desteklenmelidir. Örneğin; solunum yolu infeksiyonları için antibiyotik yönetimi, pnömoni hastalarında tedavi süresinin kısaltılmasını ve antibiyotiklerin de-eskalasyonunu, kronik obstrüktif akciğer hastalığ (KOAH) olan hastalarda bağısıklama ve așılama programlarını, antibiyotik tedavisinin yararlı olacağı sinüzit hastaları için doğru teșhisi içermektedir. Ayrıca menenjit ve pnömoni gibi bakteriyel infeksiyonlar için așılama stratejilerinin bu hastalıkların prevalansı üzerinde önemli bir etkiye sahip olduğu gösterilmiștir. Özellikle cocuklarda pnömokok așısı infeksiyon oranlarını, solunum yolu infeksiyonu nedeniyle hastaneye yatıs sıklığını, sağlık harcamalarını ve ölüm oranlarını önemli ölçüde azaltmıștır. Solunum yolu infeksiyonu nedeniyle hastaneye yatırılan yașlı hastaların, taburcu edilirken pnömokok veya influenza așısı olması önerilmektedir. Benzer șekilde üriner sistem infeksiyonlarının yönetimi için de kılavuzlarda önleyici yaklașımlar açıklanmıștır. Henüz böyle infeksiyonlar için bağıșılama stratejileri geliștirilmemiștir, ancak immünstimülasyon sağlamak için bakteri lizatları kullanılarak olumlu sonuçlar alındığı gözlenmiștir ${ }^{[20]}$.

Antibiyotik yönetim programının hastanelerde zorunlu olması, elektronik sağlık kayıtları arac1lığıyla izlenmesi, bir örgün eğitim ve araștırma programının parçası olması gerekmektedir. Antibiyotik reçeteleme davranıșlarını değiștirmede bazı girișimler etkili olsa da, toplumda bir yönetim programının uygulanması için bir kılavuz veya yerel/ulusal bir sağlık politikası bulunmamaktadır ${ }^{[20]}$.
Antibiyotik direncini azaltmak için öngörülen stratejilerin uygulanması bazen zor olabilmektedir. 2007-2010 yılları arasında Hollanda'da birinci basamak sağlık hizmeti sunan 45 merkezde yapılan bir calıșmada, doktorların antibiyotik reçeteleme davranıșının değerlendirilmesiyle, antibiyotiklerin en sik üst solunum yolu infeksiyonlarında yanlıș kullanıldığı tespit edilmiștir. Uzun süreli bakım hizmeti sunan kurulușlarda danıșmanlık hizmetlerinin titizlikle uygulanması sonucu, antibiyotik kullanımının \%25-30 azaldığ1 ve bu durumun antibiyotik direncini azalttığı rapor edilmistirir ${ }^{[20]}$.

2011 yllında, İskoc Hükümeti artan antibiyotik direnci nedeniyle stratejiler belirlemis; İskoc Antibiyotik Reçete Grubu'nun önerileri; hastanelerde ve birinci basamak tedavide antibiyotik recetelemeyi optimize etmeye, sağlık calıșanları için eğitim materyallerinin gelistirilmesine, toplumda kazanılmıs pnömoni yönetiminin gelistirilmesine ve $C$. difficile kaynaklı infeksiyon oranlarının azaltılmasına yardımc1 olmustur. Ulusal düzeyde böyle bir izlem yapilmasının, artan antibiyotik direncinin nedenlerini cözmeye yardımcı olabileceği ve yetkililere müdahale için olanak verebileceği düșünülmektedir ${ }^{[20]}$.

Antibiyotik yönetimi konusunda geniș kapsaml eğitimlerin; hükümetler, ilgili bakanlkklar ve üniversiteler tarafından, sadece sağlık calıșanları ve hastalar için değil, aynı zamanda stajyer doktorlar, ebeveynler ve cocuklar için de olusturulması gerektiği önerilmektedir ${ }^{[21]}$.

\section{ANTIBiYOTIK YÖNETIMI STRATEJILERI}

Bir antibiyotik yönetimi programı için en iyi stratejiler kesin olarak belirlenmemiștir; çünkü bu alanda yapılmıs randomize, kontrollü calısmalar yetersizdir. IDSA ve Amerika Sağllk Epidemiyolojisi Derneği antibiyotik yönetimi geliștirmek için ileriye dönük kanıta dayalı iki cekirdek strateji ve ceșitli tamamlayıcı stratejileri belirleyen kilavuz yayınlamıstır (Tablo 1$)^{[22]}$.

\section{1. Çekirdek Stratejiler}

a. Formuiler kısıtlama ve ön onay: Antibiyotik kullanımının sınırlandırılması, hastane formüler kisıtlaması yoluyla hastanede mevcut antibiyotiklere sınırl erișim veya ön onay için bir gereklilik ve kısıtlı listedeki ilaçların reçetesi için gerekçe uygulanması yoluyla elde edilebilmektedir. Her iki yöntemin antibiyotiklerin kullanımını ve maliyetini azaltmada etkili olduğu gösterilmiștir ${ }^{[22]}$. 


\section{Tablo 1. Antibiyotik yönetimi stratejileri}

1. Çekirdek stratejiler

a. Formüler kısıtlama ve ön onay

b. Müdahale ve geribildirim ile prospektif denetim

2. Tamamlayıcı stratejiler
a. Eğitim
b. Kılavuzlar ve klinik yolaklar
c. Antibiyotik istek formları
d. Tedavinin sadeleştirilmesi ya da de-eskalasyonu
e. Kombinasyon tedavisi
f. Doz optimizasyonu
g. Parenteral uygulamadan oral uygulamaya dönüş- türme
h. Antibiyotik döngüsü

$\mathrm{Bu}$ strateji, bazı onaylı endikasyonlarda, belirtilen antibiyotiklerin kullanımının sınırlamasını içermektedir. Bir antibiyotik komitesi tarafından, ajanların onaylanan kullanımına ilișkin kılavuzlar olușturulur. Bu strateji, istek yapıldığında hekimler için eğitim fırsatına ve antibiyotik kullanımı üzerinde doğrudan kontrole olanak sağlamaktadır ${ }^{[19]}$

Yapılan bir çalıșmada coklu ilaca dirençli Klebsiella pneumoniae varlı̆̆ ve seftazidim kullanımı arasındaki ilișki ile ilgili, doktor eğitimine ve antibiyotik kullanımının kısıtlanmasına yönelik, müdahale öncesi ve sonrası iki hastanede coklu ilaca dirençli $K$. pneumoniae prevalansı ölçülmüștür. Müdahale sonrasinda her iki hastanede seftazidim kullanımı azalmıs ve piperasilin-tazobaktam kullanımı artmıștır. Yapılan değișikliklerle; K. pneumoniae izolatları arasında seftazidim direncinde önemli bir azalma saptanmıștır. Antibiyotik kontrol programı ve politikası olan 10 hastaneden elde edilen verilerin retrospektif analizinde benzer incelemeler yapilmıs; belirgin nozokomiyal patojenler için antibiyotik direnc eğilimleri ve antibiyotik kullanımı karșllaștırılmıștır. Seftazidime dirençli Pseudomonas aeruginosa ve seftazidime dirençli Enterobacteriaceae prevalansı ile seftazidim kullanımı arasında güçlü bir pozitif ilișki kaydedilmiștir. Aynı sekilde kontrol programı ve politikalarıyla, bazı dirençli bakteri sușlarının daha az gözlendiği ve daha az antibiyotik kullanımı olduğu saptanmıștır ${ }^{[22]}$.

Bazı antibiyotiklerin kisitlanması, coklu ilaca dirençli patojen salgınlarını kontrol etmek için etkili bir yöntem olsa da, bu tür önlemlerin dikkatli yapılması gerekmektedir. Sefalosporinlerin veya florokinolonların yanı sıra formülerde diğer antibiyotikleri kısıtlayan bir değișiklik, yeni ve farklı direnc profilleri olan patojenlerin ortaya clkmasına neden olabilmektedir ${ }^{[22]}$. Antibiyotik kisitlanmasındaki güclükler ve bunun antibiyotik direnci üzerindeki etkilerinin değerlendirildiği bir calıșmada, sefalosporinlere dirençli Klebsiella insidansındaki bir artıs nedeniyle sefalosporin için bir ön onay politikası uygulanmıstır. Bu uygulamayla, hastane genelinde sefalosporin kullanımında \%80'lik bir azalma, tıp merkezi çapında seftazidime dirençli Klebsiella insidansında \%44'lük bir azalma, yoğun bakım ünitelerinde ise \%71'lik bir azalma olduğu saptanmıștır. Ancak, es zamanlı olarak, imipenem kullanımı \%141 artmıs ve buna imipeneme direncli $P$. aeruginosa insidansında \%69'luk bir artıs eșlik etmiștir ${ }^{[14,22]}$

b. Miidahale ve geribildirim ile prospektif denetim: $\mathrm{Bu}$ strateji, hedeflenen ajanların uygunluğunun günlük olarak incelenmesini, gerekirse alternatif ajan önermesi için reçeteyi yazan doktorla temasa gecmeyi de içermektedir. Bu stratejinin uygulanmasında, hedefe yönelik ajanların uygun kullanımı için antibiyotik komitesine, değerlendirmeleri yapmak ve günlük olarak iletisimi takip etmek için de genellikle klinik eczacılara ihtiyac duyulmaktadır ${ }^{[19]}$. Bu strateji, ön onay stratejisinden daha esnek olma ve hastaya özgü bakımı kolaylaștırma eğilimindedir. Denetimler, hastaların tanısı konulup hastalar ampirik tedaviyi aldiktan sonra yapilmaktadır ${ }^{[23]}$.

Ancak, zaman alıcı olduğundan denetimlerin yerel ihtiyaçlara ve kaynaklara göre adapte edilmesi gerekmektedir; örneğin, haftada üc gün olacak sekilde prospektif denetim, küçük bir hastane için uygun olabilmekte ve antibiyotiklerin uygun kullanımı konusunda önemli bir etki sağlayabilmektedir. Antibiyotik reçetelerinin prospektif denetimi yapilarak, biri genel serviste diğeri ise yoğun bakım ünitesinde olmak üzere iki calıșma yapılmıștır. Her iki çalıșma vankomisin ve üçüncü kușak sefalosporin tüketimini önemli ölçüde azaltmıștır. Bu bulgular, doktorun reçete özgürlüğünü kısıtlamadan reçete alıșkanlığı üzerinde önemli değisikliğe neden olabileceğini göstermektedir ${ }^{[22]}$. Bu stratejinin Boston'da orta büyüklükteki bir eğitim hastanesinde uygulanmasıly genis spektrumlu antibiyotiklerin (özellikle üçüncü kușak sefalosporin) uygunsuz kullanımında azalma sağlanmıștır. Bir 
infeksiyon hastalıkları uzmanı doktor ve infeksiyon hastalıkları konusunda eğitim almıs bir klinik eczacıdan olușan antibiyotik yönetimi ekibi tarafından parenteral üçüncü kușak sefalosporin, aztreonam, parenteral florokinolon veya imipenem alan tüm hastalar için antibiyotik istemleri incelenmistir. Antibiyotik yönetim ekibinin önerileri, reçeteyi yazan doktorlara iletilmiștir. Programın uygulanmasını takiben parenteral antibiyotik maliyeti yaklaș1k \%30 azalırken, parenteral antibiyotik kullanımı da giderek azalmiștır ${ }^{[19]}$.

\section{Tamamlayıcı Stratejiler}

a. Eğitim: Eğitim, reçeteleme davranıșını etkilemek için tasarlanmıș bir yönetim programı için gerekmektedir. Ancak pasif eğitim yoluyla antibiyotik reçeteleme davranısıını etkileme cabaları, marjinal etkili gibi görünmekte ve sürekli bir etkiye sahip olmamaktadır ${ }^{[14,22]}$. Avantaj1, reçeteleme davranıșını etkileyebilmesi iken; dezavantajı, aktif müdahale olmadan kullanıldığında, reçeteleme davranıșını değiștirmede sadece marjinal olarak etkili olmasıdır [23]

b. Kılavuzlar ve klinik yolaklar: Yerel mikrobiyoloji ve direnç örneklerinin/șablonlarının dahil edildiği kanıta dayalı kılavuzların multidisipliner olarak geliștirilmesi, antibiyotik tedavisinin yararlılığını artırabilmektedir ${ }^{[14,22]}$. Kılavuzlara olan uyum, her ne kadar \%18-33 arasında olsa da; reçete yazan doktorlarla yakın işbirliğinin periyodik güncellemelerle geliștirilmesini sağlamaktadır ${ }^{[22]}$. Avantajı, antibiyotik kullanımını iyileștirebilmesi ve uygulama farklılıklarını ortadan kaldırabilmesi; dezavantajı ise, uyumun düsüuk olmasıdır ${ }^{[23]}$.

c. Antibiyotik istek formları: Yaplan bir calıșmada; antibiyotik istek formu programı, antibiyotik kullanımının devam eden, es zamanl denetimini sağlamak için 800 yataklı bir hastanede yatan hastaların tümüne uygulanmıștır. Reçete yazan doktorlar tarafindan antibiyotik istekleri için klinik endikasyon tanımlanmıș ve bireysel olarak her hasta için tedavi kürleri belirlenmistir. Antibiyotik istek formlarının girilmesinden sonra, antibiyotik tedavi kürlerinde ve antibiyotik alan hasta yüzdesinde önemli bir düșuss saptanmıștır. $\mathrm{Bu}$ calıșmada, özel antibiyotik istek formunun antibiyotik kullanımının incelenmesi için etkili bir yöntem olduğu ve hekimin reçeteleme davran1ș1 üzerinde önemli bir etkiye sahip olabileceği sonucuna varılmıstır. Bunun aksine, bașka bir calıșmada; antibiyotik istek formu programının uygulanmasının, pediatride vankomisin kullanımının azaltılması ve iyileștirilmesi üzerine etkisi olmadığı gösterilmiștir ${ }^{[22]}$. Bu yöntemin avantajı, uygunsuz antibiyotik kullanımını azaltabilmesi, kılavuzlar ve klinik yolakların uygulanmasını kolaylaștırabilmesidir. Dezavantajı ise, otomatik sonlandırma orderları nedeniyle tedavide uygunsuz olarak kesinti gözlenme olasılığı görülebilmesidir ${ }^{[23]}$.

d. Tedavinin sadeleștirilmesi ya da de-eskalasyonu: De-eskalasyon stratejisi, kritik hastalığı olan hastalarda daha yüksek sağkalımla ilișkili olan uygun ampirik antibiyotik tedavisi kavramına dayanmaktadır. Bu nedenle, ciddi infeksiyonların ampirik tedavisi için tek bașına veya kombine olarak geniș spektrumlu antibiyotik kullanımı önerilmektedir. De-eskalasyon teorisi, klinik yanıt ve kültür bulgularına dayalı antibiyotik tedavisini tanımlamak için, hastanın yeniden değerlendirilmesi gerektiğini önermektedir. Fakat günlük pratikte, yoğun bakımda pozitif kültürlerin düșük yüzdesi ve yoğun bakım hastalarının klinik yanıtının değerlendirilme zorluğu dahil olmak üzere, hekimlerin de-eskalasyonu gerçekleștirememesinin çeșitli nedenleri bulunmaktadır. Bu durumda infeksiyon hastalıkları doktoru, antibiyotik tedavisini ayarlamak ve klinik sonucları etkilemeden maliyet açısından tasarruf sağlamada yardımcı olabilmektedir $^{[22]}$. Yöntemin avantajı, antibiyotiklere maruz kalmayı, dirençli patojenlerin seçimini ve sağlık bakım maliyetlerini azaltmasıdır. Dezavantajı ise, klinik iyileșme gözlendiğinde ve kültür sonuçları negatif olduğunda reçete yazan doktorun de-eskalasyon için isteksiz olabilmesidir ${ }^{[23]}$.

e. Kombinasyon tedavisi: Kombinasyon tedavisinin, sonuçların iyileștirilmesi veya direnç gelișiminin önlenmesi üzerindeki etkisini destekleyen veri eksikliği nedeniyle rutin olarak kullanımı önerilmemektedir ${ }^{[14,19]}$. Yapılan bir calıșmada, kombine antibiyotik tedavisinin gram-negatif bakteremisi olan hastalarda mortaliteyi azaltmadığı belirtilmiștir. Bașka bir calıșmada ise, direncin ortaya çımasını önlemek için; kombinasyon tedavisinin rutin kullanımını önermek için verilerin yetersiz olduğu bildirilmiștir ${ }^{[22]}$. Bu verilere dayanarak kombine antibiyotik tedavisi; coklu ilaca direncli patojenlerle infeksiyon riski altında ve kritik hastalığı olan hastalar için ampirik tedavinin kapsamın genișletilmesi ve bașlangıc tedavisinin bașarı olasılığının artırılmasını sağlamak üzere bazı klinik 
durumlarda kullanılmaktadır ${ }^{[14,22]}$. Avantajı, klinik sonucları iyileștirebilmesi ve hastaların bazılarında direnç gelișimini önleyebilmesidir. Dezavantajı ise, genellikle gereksizdir, iyileștirilmiş klinik sonuçları ve direncin önlenmesini gösteren verilerin yetersiz olmasidir ${ }^{[23]}$.

f. Doz optimizasyonu: Hastaya ait özelliklere, etken organizmaya, infeksiyon bölgesine ve ilacın farmakodinamik ve farmakokinetik profiline göre antibiyotiklerin dozlarının optimizasyonu, antibiyotik yönetim programlarının önemli bir bilesenidir ${ }^{[14,22]}$. Doz optimizasyon stratejileri, farmakokinetik ve farmakodinamik parametrelerini göz önünde bulundurarak, gerektiğinde vankomisini daha yüksek dozda ve beta-laktamları uzun süreli infüzyon seklinde kullanabilmeyi içerebilmektedir. Serum antibiyotik konsantrasyonu, minimum inhibitör konsantrasyonunun üzerinde olduğunda, beta-laktam antibiyotiklerin terapötik etkisi ile farmakokinetik ve farmakodinamik parametreler korelasyon göstermektedir ${ }^{[2]}$. Yöntemin avantaj1; hasta özelliklerine, etken organizmaya, infeksiyon bölgesine ve antibiyotiğin farmakokinetik ve farmakodinamik özelliklerine göre uygun tedavinin sağlanmasıdır. Dezavantajı ise, farmakokinetik parametrelere dayalı uzun süreli infüzyon kullanıld1ğında hemșirelerde uygulamaya yönelik endișelere yol acmasidir ${ }^{[23]}$.

g. Parenteral uygulamadan oral uygulamaya geçiș: Güvenli ve etkili olduğu gösterilmiș, yaygın olarak kullanılan bir yöntemdir. Ayrıca kapsamlı olarak alınmıș eğitim gerektirmeyen personel tarafından uygulanabilmektedir. 2013 yılında yayınlanan bir çalıșmada, gazilerin tedavi aldığı bir hastanede intravenöz florokinolon kullanımının sonlandirılmasıyla 2006-2010 yılları arasında 4 milyon dolar kadar tasarruf sağlandığı bildirilmiștir ${ }^{[24]}$. Hastanede kalıs süresini ve sağlık bakım maliyetini azaltmak için etkili bir stratejidir ${ }^{[22]}$. Basit, maliyet-etkin ve genellikle klinisyenler tarafından iyi kabul gören bir uygulamadir ${ }^{[10]}$. Avantajı, intravenöz erișimden kaynaklanan komplikasyon riskini azaltabilmesidir. Dezavantajı ise, uygulama yolu geçiși için uygun olan hastaların belirlenmesindeki zorluktur ${ }^{[23]}$.

h. Antibiyotik dönguisui: Antibiyotik döngüsü, antibiyotik direncinin ortaya çımasını önlemek veya tersine cevirmek için bir kurumda antibiyotik sınıflarının veya spesifik antibiyotiklerin bir bașka grup/antibiyotik ile değiștirilmesini gerektirmektedir. Antibiyotik döngüsünün rutin kullanımını önermek için veriler ne yazık ki yeterli değildir. Planlanan antibiyotiğin düzenli olarak değiștirilmesi gerekmektedir. Reçeteyi yazan doktor, planlanan antibiyotikten habersiz olabileceğinden, bu programlara uyum zor olabilmektedir ${ }^{[22]}$. Avantaji, antibiyotik kullanım ceșitliliği sağlayarak direnci en aza indirebilmesidir. Dezavantajı ise, uzun dönemde antibiyotik direncini azaltan etkinliği gösteren yeterli veri olmamasıdır. Antibiyotik maliyetleri artabilmektedir ${ }^{[23]}$.

\section{ANTIBiYYOTIK YÖNETIM PROGRAMLARININ ETKINLIĞi}

1980-2003 yılları arasında yayınlanan randomize kontrollü calıșmalar, kontrollü çalıșmaların öncesi ve sonrası, hastanede yatan hastalar için antibiyotik reçeteleme uygulamalarını geliștirmeyi amaçlayan araștırmalar gözden geçirilmiș; 60'1 antibiyotik kullanımını azaltmayı amaçlayan olmak üzere, toplam 66 çalıșma bir meta-analize dahil edilmiștir. Calıșmalarda hedeflenen temel konu, antibiyotik kullanımının optimizasyonu olmakla birlikte; mikrobiyolojik (antibiyotik dirençi bakterilerin prevalansi) veya klinik sonuclar (hastanede kalıs süresi ve mortalite) çalıșmaların sadece bir kısmında belirtilmiștir. Yapılan meta-analize göre; calıșmaların \%81'inde ilgili müdahaleler sonucunda ilaç kullanımının optimizasyonunun sağlandığı görülmüștür. Müdahalelerin net etkisi \%8-69 arasında değișmektedir. Calıșmaların \%75'inde mikrobiyolojik sonuçların iyileștiği gözlenmekle beraber, antibiyotik direnç oranı üzerine etkisi için en somut kanıtlar, $C$. difficile ile ilișkili hastalık insidansını azaltmayı amaçlayan calıșmalarla sağlanmıștır. Antibiyotik kısıtlama politikasının hastalar üzerinde herhangi bir yan etkisi saptanmamıstır. Mortalite oranlarında elde edilen sonucların ise calıșmalar arası farklılık gösterdiŏi belirtilmiștir. Sonuc olarak, antibiyotik yönetim programlarının hastanelerde antibiyotik kullanımını iyileștirebileceği, ancak hastalardaki klinik yararları değerlendirmek için daha fazla calıșmaya ihtiyaç olduğu bildirilmiștir ${ }^{[25]}$.

Son yıllarda yapılan calıșmalarla antibiyotik tedavisinin yeniden değerlendirilmesinin, antibiyotiklerin uygun kullanımı konusunda önemli bir adım olduğu gösterilmiștir. Hastanede yapılan bir calıșmada, 10 yıldır uygulanan ön onay sistemi ile klinisyenler tarafından farklı geribildirim yön- 
temleri kullanılarak, 48-72 saat devam eden tedavinin sistematik olarak gözden geçirilmesinin etkisi değerlendirilmiș; klinisyenler ve uygulanan farkl geribildirim yöntemleri arasında yüksek oranda bir uyum (\%72) olduğu gözlenmiștir ${ }^{[25]}$.

\section{ANTIBiYYOTIK YÖNETIMi EKIBíNDE ECZACININ ROLÜ}

Eczacılar, infeksiyon hastalıkları uzmanı doktor ve diğer hastane personelinin de katılımıyla antibiyotik yönetim programının geliștirilmesi ve uygulanmasında etkili olabilmektedir. ABD'de yapilan bir çalıșada, antibiyotik yönetim eczacısı liderliğinde 325 yataklı bir hastanede bir antibiyotik yönetim programı uygulanmıștır. Eczacı, belirli günler hastanın tedavisini gözden geçirmek ve günlük durumunu görüșmek için doktorlarla iletisime gecmiștir. Eczacı, programın ilk 33 ayında \%91.8 kabul oranı ile toplam 2457 müdahalede bulunmustur. Program uygulanmadan önce ve uygulandıktan sonraki bir yıllık sonuclar karșılastırıldığında, yaygın olarak kullanılmakta olan karbapenem, daptomisin, ekinokandin, levofloksasin antibiyotiklerinin uygulama sonrası dönemde kullanımında ve toplumda kazanılmıș pnömoni için ortalama hastanede kalıș süresinde önemli düșüșler gözlenmiștir. Programın uygulanmasından iki yil sonra, yıllık tasarrufunun yaklașı 355.000 dolar olduğu tahmin edilmiștir ${ }^{[26]}$.

Brezilya'daki bir kardiyoloji hastanesinde yaplan calıșmada ise, eczacı olmadan uygulanan antibiyotik yönetim programının etkisi değerlendirilmiștir. Program bir infeksiyon hastalıkları uzmanı doktor liderliğinde uygulanmıștır. Yirmi iki ay sonra ekibe eczacı dahil edilmiștir. Calıșmanın birinci așamasında uygulanmaya bașlanan programın etkisini değerlendirmek için, ikinci așamasında infeksiyon hastalıkları uzmanı doktorun katkısını değerlendirmek için, üçüncü așamada ise eczacı katılımının etkisini değerlendirmek için veriler toplanmıștır. Program bașladiktan sonra tüm antibiyotiklerin tüketiminde önemli bir azalma olmustur. Bununla birlikte, üçüncü așamada eczacı florokinolon, klindamisin, ampisilin-sulbaktam tüketiminin ve sefalosporin kullanımındaki artıșın azalmasına önemli ölçuide katkıda bulunmuștur. Calıșma boyunca ekibin tavsiyelerine \%64.1 oranında uyulmustur. Sonuc olarak hastanede antibiyotik maliyetinde \%69 azalma gözlenmiștir. Sınırlı kaynaklara sahip bir ülke için pahalı olmayan antibiyotik yönetim programının uygulanması, antibiyotik tüketimini ve maliyetini belirgin ölçüde azaltmıștır ${ }^{[27]}$.

Eczacıların katkısını değerlendiren cok sayıda çalıșma bulunmaktadır. Parenteral sefalosporinin uygun dozda kullanılması ile yıllık 45.000 dolar tasarruf sağlandığı bildirilmiștir. Seftriaksonun uygun endikasyonda ve dozda kullanılmasıyla yıllık 200.000 dolardan daha fazla tasarruf sağlanmıștır. Parenteral tedaviden oral tedaviye geçis programıla sağlanan yıllık tasarrufun 13.000-163.000 dolar, terapötik değiștirme programları ile sağlanan yllık kazancın ise 10.000-178.000 dolar arasında değiștiŏi gösterilmiștir ${ }^{[28]}$.

Yapılan bir bașka çalıșmada, İngiltere'de bulunan hastanelerde eczacı liderliğindeki antibiyotik yönetim faaliyetlerinin gelișimi değerlendirilmiș ve hastanelerdeki antibiyotik eczacılarına ve bas eczacılara elektronik anket uygulanmıstır. 2005 ve 2011 yıllarındaki veriler karșılaștırıldığında, 2005 yılından itibaren antibiyotik uzmanı eczacı sayısı ve bu eczacıların deneyimlerinde artıs olduğu gösterilmiștir. Hastanelerin \%95'inden fazlası ampirik kullanım rehberlerine, antibiyotik formüleri ve cerrahi profilaksi kılavuzlarına uyum sağlamıștır. Intravenöz uygulamadan oral uygulamaya geçiș programı ise \%87 oranında uygulanmıștır. Bu oranlar 2005 yılından 2011 yılına kadar artıs göstermiștir. Eczacıların antibiyotik yönetiminde giderek artan rolü, bu rolü genișletmek ve daha fazla multidisipliner katılım sağlamak için hastanelere olanak sağlamıștır ${ }^{[29]}$

İnfeksiyon hastalıkları konusunda deneyimli olan klinik eczacı sayısındaki artıs ile 2000 y1lından bu yana antibiyotik eczacılığı bir uzmanlık alanı olarak gelișme göstermiștir. Bu eczacılar genellikle antibiyotiklerin kullanımı ve yönetimi ile ilgili klinik danıșmanlık yapmak, antibiyotik kılavuzlarını hazırlamak ve formüler olușturmak gibi faaliyetlerde bulunmaktadir. Eczacilar, infeksiyon hastalıkları ekibi içerisinde uzmanlık eğitimi ve eğitim rotasyonları yoluyla klinik becerilerini geliştirmektedir. Bu amaçla geliștirilen eğitim programı bes alanı kapsamaktadır (Tablo 2) ${ }^{[30]}$

Amerika Hastane Eczacıları Birliği ve İnfeksiyon Hastalıkları Eczacıları Derneği; infeksiyon hastalıkları lisansüstü eğitimi kapsamında, eczacıların așağıdaki konulara yönelik bilgi sahibi olmalarını önermektedir ${ }^{[31]}$. 
- Klinik mikrobiyoloji laboratuvarının temelleri

- İnfeksiyon hastalıkları danıșmanlık hizmeti

- Antibiyotik sürveyans programı

- İlac bilgi merkezi

- İnfeksiyon kontrolü

- Farmakoekonomi ve sağllk ekonomisi

$\mathrm{Bu}$ bilgilerin yanında eğitim sürecinin; kardiyovasküler sistem infeksiyonları, santral sinir sistemi infeksiyonları, üst solunum yolu infeksiyonları, idrar yolu infeksiyonları, oftalmolojik infeksiyonları, fungal infeksiyonları ve viral infeksiyonları olan hastaların bakımı konularını da içermesi önerilmektedir. Dolayısıyla, eğitim içeriŏinin antibakteriyel, antifungal, antiretroviral, antiviral, antiparaziter ve immünmodülatör ajanları kullanan hastaların bakımını içermesi de gerekmektedir ${ }^{[31]}$.

Antibiyotik yönetiminde, infeksiyonların önlenmesi ve kontrolünde eczaciların görev ve sorumlulukları; antibiyotiklerin akılcı kullanımını tesvik etmek, infeksiyonların yayılmasını azaltmak, sağlık calıșanlarını, hastaları ve halkı eğitmek olarak sıralanabilir [32]

\section{Antibiyotiklerin Akılcı Kullanımının Tesvik Edilmesi}

Antibiyotiklerin profilaktik, ampirik ve terapötik kullanımını sağlayarak hastanın tedavi sonuçlarının optimize edilmesi için sağllk sistemi içinde multidisipliner ișbirliğinin teșvik edilmesi gerekmektedir. $\mathrm{Bu}$ faaliyetler; antibiyotiklerin uygun seçimi, optimal doz, uygun izleme ve antibiyotik tedavisinin de-eskalasyonunu içerebilmektedir. Bunun yanı sıra antibiyotik kullanım prosedürlerinin, terapötik değișimin, tedavi kılavuzlarının ve klinik bakım planlarının geliștirilmesi de eczacının aktif ola- rak katılacağı alanlar olarak belirtilebilir. Eczacılar; hastalar için uygun olan antibiyotiklerin ceșitlerini ve sayılarını belirlemek için infeksiyon hastalıkları ile iliskkili "Illac ve Tedavi Komitesi" bünyesinde calıșmalıdır. Komitelerce alınan bu tür kararlar, mikroorganizmaların dirençli suşlarının ortaya cıkmasını en aza indirirken, optimal terapötik sonuçlar sağlayan antibiyotik kullanım politikalarının geliștirilmesi açısından da önemlidir. Bu amaçla; antibiyotik kullanımıyla ilgili olarak klinik ve ekonomik sonuc analizlerini gerçekleștirmek için, antibiyotik kullanımı konusunda nicel veri olusturulmalı ve analiz yapılmalı; her hasta için, zamanında rapor edilmis uygun mikrobiyal duyarlllk testlerini sağlamak için mikrobiyoloji laboratuvar personeli ile calıșlmall; sürveyans, sonuc raporlama ve klinik karar destek sistemlerinin gelișimi yoluyla antibiyotik yönetimini geliștirmek için bilgi teknolojisi kullanilmalı; olası hataları ve advers olayları azaltmak için etkin ve etkili sistemler kullanılarak antibiyotiklerin güvenli ilaç yönetimi uygulamaları kolaylaștırılmalıdır.

\section{İnfeksiyonların Yayılmasının Azaltılması}

Eczacıların; hastalar, sağlık calıșanları ve diğer insanlar arasında infeksiyonların yayılmasını azaltmak ve önlemek için infeksiyon önleme ve kontrol komitelerine aktif olarak katılması sağlanmalı; eczane tarafından dağıtılan veya hazırlanan ilaçların kontaminasyonunu önlemek için eczane politikalar1, prosedürleri ve kalite kontrol programları olusturulmalı (steril ürünlerin hazırlanması ve kullanımı, farmasötik ekipmanların temizliğinin sağlanması ve uygun personel politikalarının olușturulması); steril ortam dișında cok dozluk ambalaj yerine, steril ürünler için tek dozluk ambalajların

Tablo 2. Infeksiyon eczacılı̆ı eğitim programı kapsamı

\begin{tabular}{ll} 
Kapsam & İçerik \\
\hline Infeksiyon ve antibiyotik yönetimi & $\begin{array}{l}\text { Yerel, ulusal antibiyotik kullanımı ve direnç verilerinin yorumlanması, } \\
\text { antibiyotik yönetimi ile ilgili ulusal ve uluslararası politika, antibiyotik } \\
\text { direnci } \\
\text { Klinik mikrobiyoloji }\end{array}$ \\
$\begin{array}{l}\text { Laboratuvar testleri ve bunların yorumlanması, infeksiyonun klinik } \\
\text { ilkeleri ve antibiyotik direncinin ilkeleri } \\
\text { Terapötik ilaç izlemi, antibiyotiklerin farmakolojik, farmakodinamik ve } \\
\text { farmakokinetik özellikleri, özel popülasyonda kullanılan antibiyotikler } \\
\text { Klinik sendromların yönetimi }\end{array}$ & $\begin{array}{l}\text { Vücut sistemleriyle birlikte değerlendirme } \\
\text { Yönetim ekibinin rolü, hastane ve birinci basamak yönetim program- } \\
\text { larının anahtar bileşenleri }\end{array}$ \\
\hline & \\
&
\end{tabular}


kullanılması tesvik edilmeli; cok dozluk steril ürün kapları ve steril ürünlerin uygun etiketlenmesi, tarihlendirilmesi ve saklanması için öneride bulunulmalı; hasta bakım ortamını etkileyen hastane personeli ve diğer kișilerin rutin olarak așlanmasını ve sağlık sistemi politikası veya yerel düzenlemelere uygun olarak seçilen bulașicı hastalıklar icin periyodik tarama yapilması tesvik edilmeli; hasta bakım ortamını etkileyen sağlık calıșanlarının, hastaların ve diğer personelin standart önlemlere uyması tesvik edilmeli; bulașıcı hastalığı olan kișiler ile temasta bulunmus sağlık çalıșanları ve hastaların izlenmesi, tedavisi ve riskin değerlendirilmesi için kllavuzların geliștirilmesinde ișbirliği yapılmalı; cerrahi alan infeksiyonları, katetere bağlı kan dolașımı infeksiyonları ve katetere bağlı idrar yolu infeksiyonları dahil olmak üzere hasta bakımı ile ilișkili infeksiyonların sıfır toleransı için çaba sarf edilmesi sağlanmalıdır ${ }^{[32]}$.

\section{Eğitim Faaliyetleri}

Sağlık sisteminin uygulaması ile ilișkili olan halka, hastalara, infeksiyon önleme ve kontrol çalısanlarına antibiyotik yönetimi hakkında bilgi ve eğitim vermek eczacıların sorumluluğu arasında yer almaktadır. Formuiler kısıtlama ve ön onay gibi aktif müdahale tekniklerini birlestirmek, hasta bakım alanında eğitim faaliyetlerinin etkinliğini artırmaktadır. Bu amaçla yapılacak eğitim faaliyetleri așağıdaki aktiviteleri içerebilirr ${ }^{[32]}$

- Antibiyotik kullanımı ve direnci, dekontaminasyon ajanları, aseptik teknik ve prosedürleri ve sterilizasyon yöntemleri gibi konularda sağlık çalıșanları için bültenler ve klinik konferanslar vermek.

- Yatan hastalara, ayakta tedavi alan hastalara, evde bakılan hastalara ve onların ailelerine antibiyotiklerin reçetede yazıldığı gibi kullanılması gerektiği, ilaçların kullanılması ve saklanması, cihazların uygulanması ve diğer infeksiyon önleme ve kontrol prosedürleri ile ilgili danıșmanlı yapmak ve eğitim vermek.

- Infeksiyon hastalıklarının yayılmasını kontrol etmeyi amaçlayan halk sağlığı bilinçlendirme ve eğitim programlarına katılmak.

- Eczacılar, öğrenciler ve araștırmacıların deneyimsel ve öğretici eğitim yoluyla infeksiyon önleme ve kontrol uygulamaları ile antibiyotik yönetimi konusunda bilgi sahibi olmasını sağlamak.

\section{TARTIȘMA ve SONUÇ}

Antibiyotik direnci hızlı bir sekilde artıș göstermektedir ${ }^{[11]}$. Antibiyotik direncinin gelișimi, hem toplum hem de hastane ortamında infeksiyonların yönetimi için kritik bir sorun olmaya devam etmektedir ${ }^{[20]}$. Bu nedenle yeni antibiyotiklerin geliștirilmesi muhtemeldir ${ }^{[12]}$. Ancak az sayıda yeni antibiyotik olmasına rağmen antibiyotik direnci oranları artmaktadir ${ }^{[33]}$. Antibiyotik yönetim programlarının geliștirilmesi, antibiyotik kullanımının iyileștirilmesi ve antibiyotik direncli patojenlerin ortaya çımasını önlemek için önemlidir ${ }^{23]}$. Antibiyotik yönetim programının uygulanması; antibiyotiklerin uygun doz, zaman ve sürede kullanilmasını sağlayarak, antibiyotik tedavi ilkeleri ile uyumu artırarak ve gereksiz antibiyotik kullanımını azaltarak hasta sonuçlarını iyileștirmektedir ${ }^{[10]}$. Aynı zamanda antibiyotik yönetim programlarının maliyet tasarrufu sağladığı gösterilmiștir ${ }^{[25]}$. Özellikle coklu ilaca dirençli mikroorganizmalar ve $C$. difficile nedeniyle infeksiyona yakalanma riskini de azaltmaktadir ${ }^{[10]}$. Bu programlar infeksiyon hastalıkları uzmanı doktor veya klinik eczacı liderliğinde uygulanabildiği gibi uzman olmayan eczacı tarafından da uygulanabilmektedir ${ }^{[23]}$. Genel olarak programın bașarısı; stratejilerin uygulanması, antibiyotik reçetelerinin izlenmesi ve eğitim için koordineli multidisipliner bir yaklașıma bağlıdır ${ }^{[34]}$. Yönetim programları sadece büyük ölçekli hastaneler için değil aynı zamanda küçük ölçekli hastaneler için de gereklidir ${ }^{[23]}$. Hastane ortaminda antibiyotik yönetimi programlarının uygulanmasının antibiyotiklerin uygun kullanımı konusunda olumlu etkiye sahip olduğu gösterilmiștir. Bununla birlikte toplumda benzer programları uygulamak zordur. Sonuc olarak klinik sonucları iyilestirmek ve direnç gelișimini azaltmak için önleyici stratejiler sağlık çalıșanlarının ve hastaların eğitimi ile daha fazla tesvik edilmelidir ${ }^{[20]}$. Doktorların reçete yazarken antibiyotik yönetimi ilkelerine uyması ve yönetim ekibine destek vermesi önemlidir ${ }^{[11]}$. Eczaciların antibiyotik yönetimi, infeksiyon önleme ve kontrol programlarında önemli rolleri ve sorumlulukları vardır. Bu nedenle eczaciların antibiyotiklerin uygun kullanılmasını sağlamak için antibiyotik yönetimi ekibine aktif olarak katılması gerekmektedir ${ }^{[32]}$.

\section{KAYNAKLAR}

1. Hara GL. Antimicrobial stewardship in hospitals: does it work and can we do it? J Glob Antimicrob Resist 2014;2:1-6.

2. Knox $K$, Lawson $W$, Dean B, Holmes A. Multidisciplinary antimicrobial management and the role of the infectious diseases pharmacist-a UK perspective. J Hosp Infect 2003;53: 85-90. 
3. Etienne P, Roger PM, Brofferio P, Labate C, Blanc V, Tiger F, et al. Antimicrobial stewardship program and quality of antibiotic prescriptions. Med Mal Infect 2011;41:608-12.

4. The Society of Hospital Pharmacists of Australia. Medicines in Focus Antimicrobial stewardship. 2012 [cited 2014 18.10.2014]; Available from: http://www.shpa.org.au/lib/ pdf/positionstatement/Medicines_in_Focus_Antimicrobial_ stewardship_fact_sheet_July_2012.pdf.

5. Goff DA. Antimicrobial stewardship: bridging the gap between quality care and cost. Curr Opin Infect Dis 2011;24(Suppl 1):S11-20.

6. Bisht $R$, Katiyar $A$, Singh $R$, Mittal P. Antibiotic resistance: $A$ Global Issue of Concern. Asian J Pharm Clin Res 2009;2:34-9.

7. File $T M$ Jr, Srinivasan A, Bartlett JG. Antimicrobial stewardship: importance for patient and public health. Clin Infect Dis 2014;59(Suppl 3):S93-6.

8. Fishman N. Antimicrobial stewardship. Am J Med 2006;119(6 Suppl 1):S53-61; discussion S62-70.

9. Leuthner KD, Doern GV. Antimicrobial stewardship programs. J Clin Microbiol 2013;51:3916-20.

10. Moehring RW, Anderson DJ. Antimicrobial stewardship as part of the infection prevention effort. Curr Infect Dis Rep 2012;14:592-600.

11. Hand K. Antibiotic stewardship. Clin Med 2013;13:499-503.

12. The Society for Healthcare Epidemiology of America, The Infectious Diseases Society of America, and T.P.I.D. Society, Policy Statement on Antimicrobial Stewardship by the Society for Healthcare Epidemiology of America (SHEA), the Infectious Diseases Society of America (IDSA), and the Pediatric Infectious Diseases Society (PIDS). Infect Control Hosp Epidemiol 2012;33:322-7.

13. Doron S, Davidson LE. Antimicrobial stewardship. Mayo Clin Proc 2011;86:1113-23.

14. Dellit TH, Owens RC, McGowan JE Jr, Gerding DN, Weinstein RA, Burke JP, et al; Infectious Diseases Society of America; Society for Healthcare Epidemiology of America. Infectious Diseases Society of America and the Society for Healthcare Epidemiology of America guidelines for developing an institutional program to enhance antimicrobial stewardship. Clin Infect Dis 2007;44:159-77.

15. Bartlett JG. A call to arms: the imperative for antimicrobial stewardship. Clin Infect Dis 2011;53(Suppl 1):S4-7.

16. Rohde JM, Jacobsen D, Rosenberg DJ. Role of the hospitalist in antimicrobial stewardship: a review of work completed and description of a multisite collaborative. Clin Ther 2013;35:751-7.

17. MacDougall C, Polk RE. Antimicrobial stewardship programs in health care systems. Clin Microbiol Rev 2005;18:638-56.

18. Beena PM. Antimicrobial stewardship to optimize antimicrobial use. J Clin Biomed Sci 2013;3:157-8.

19. Drew RH. Antimicrobial stewardship programs: how to start and steer a successful program. J Manag Care Pharm 2009;15:S18-S23.

20. Garau J, Nicolau DP, Wullt B, Bassetti M. Antibiotic stewardship challenges in the management of communityacquired infections for prevention of escalating antibiotic resistance. J Glob Antimicrob Resist 2014;2:245-53.
21. Pulcini C, Gyssens /C. How to educate prescribers in antimicrobial stewardship practices. Virulence 2013;4:192-202.

22. Curcio D. Antibiotic stewardship: possibilities when resources are limited. In: Vincent JL (ed). Intensive Care Medicine. New York: Springer, 2010:257-69.

23. Septimus EJ, Owens RC Jr. Need and potential of antimicrobial stewardship in community hospitals. Clin Infect Dis 2011;53(Suppl 1):S8-S14.

24. Gauthier TP, Unger NR. Antimicrobial stewardship programs: a review for the formulary decision-maker. Formulary 2013;48:7.

25. Lesprit P, Brun-Buisson C. Hospital antibiotic stewardship. Curr Opin Infect Dis 2008;21:344-9.

26. Waters CD. Pharmacist-driven antimicrobial stewardship program in an institution without infectious diseases physician support. Am J Health Syst Pharm 2015;72:466-8.

27. Magedanz L, Silliprandi EM, dos Santos RP. Impact of the pharmacist on a multidisciplinary team in an antimicrobial stewardship program: a quasi-experimental study. Int J Clin Pharm 2012;34:290-4.

28. Milkovich G. The role of the hospital pharmacist in cost control and antibiotic policy. Int / Antimicrob Agents 2000;16:291-4.

29. Wickens HJ, Farrell S, Ashiru-Oredope DA, Jacklin A, Holmes A; Antimicrobial Stewardship Group of Department of Health Advisory Committee on Antimicrobial Resistance and Health Care Associated Infections (ASG-ARHAI). The increasing role of pharmacists in antimicrobial stewardship in English hospitals. J Antimicrob Chemother 2013;68:2675-81.

30. Sneddon J, Gilchrist M, Wickens H. Development of an expert professional curriculum for antimicrobial pharmacists in the UK. J Antimicrob Chemother 2015;70:1277-80.

31. Ernst EJ, Klepser ME, Bosso JA, Rybak MJ, Hermsen ED, Segarra-Newnham $M$, et al. Recommendations for training and certification for pharmacists practicing, mentoring, and educating in infectious diseases pharmacotherapy. Pharmacotherapy 2009;29:482-8.

32. ASHP statement on the pharmacist's role in antimicrobial stewardship and infection prevention and control. Am J Health Syst Pharm 2010;67:575-7.

33. Griffith M, Postelnick M, Scheetz M. Antimicrobial stewardship programs: methods of operation and suggested outcomes. Expert Rev Anti Infect Ther 2012;10:63-73.

34. Pollack LA, Srinivasan A. Core elements of hospital antibiotic stewardship programs from the Centers for Disease Control and Prevention. Clin Infect Dis 2014;59(Suppl 3):S97-100.

\section{Yazıșma Adresi/Address for Correspondence}

Doc. Dr. Kutay DEMIRKAN

Hacettepe Üniversitesi Eczacılık Fakültesi

Klinik Eczacılık Anabilim Dalı

Ankara-Türkiye

E-posta: kutay@hacettepe.edu.tr 
